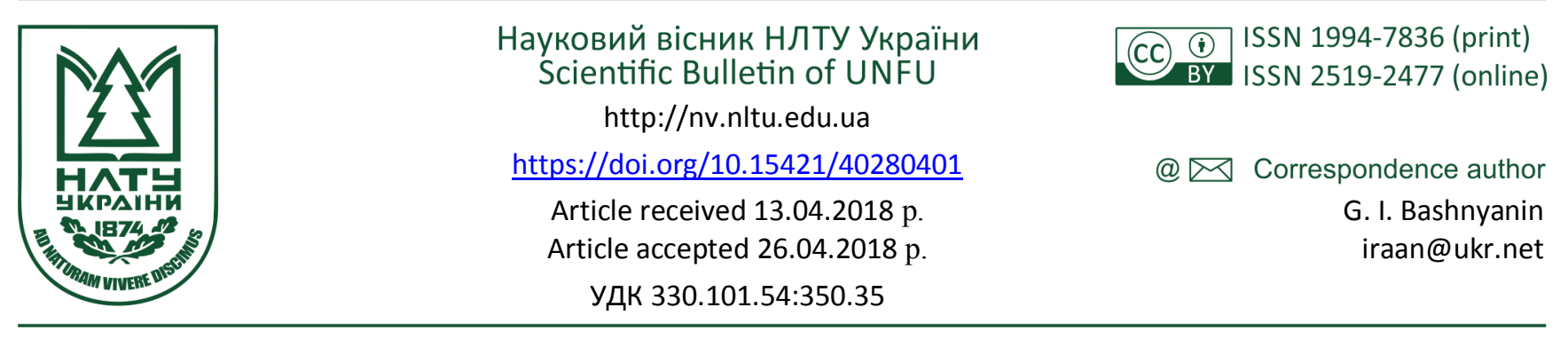

Г. І. Башнянин ${ }^{1}$, О. М. Свінцов², В. М. Коцупей ${ }^{1}$

${ }^{1}$ Львівський торговельно-економічний університет, м. Львів, Украӥна

${ }^{2}$ Дрогобицький державний педагогічний університет ім. Івана Франка, м. Дрогобич, Украйна

\title{
ЕКОНОМІЧНА ЕФЕКТИВНІСТЬ ФУНКЦІОНУВАННЯ ГОСПОДАРСЬКИХ СИСТЕМ: ПРОБЛЕМА ВИМІРЮВАННЯ
}

\begin{abstract}
Проведено науковий аналіз проблеми ефективності економічних систем у контексті виміру її точності. Досліджено сумарний економічний ефект у короткотривалому, довготривалому, гіпердовготривалому та історичному періодах часу. Запропоновано перейти від виміру статичної до квазідинамічної, динамічної, гіпердинамічної та історичної економічної ефективності функціонування економічних систем. 3 метою максимально точного виміру цієї ефективності обгрунтовано використання інтегрального економічного ефекту, який охоплює економічну, соціально-економічну і соціально-духовну складові. Зроблено висновок про те, що економічну ефективність функціонування економічних систем визначають як співвідношення економічного ефекту й економічних витрат. Економічні витрати формуються в кожен конкретний момент часу. Внаслідок зіставляння поточного економічного ефекту (в короткотривалому періоді) з поточними економічними витратами отримано неточне або номінальне значення економічної ефективності, оскільки економічний ефект проявляється через певний лаг часу, який може бути доволі значним. Реальне значення рівня ефективності отримаємо тоді, коли буде зіставлено поточні економічні витрати зі сумарним ефектом, який формується у віддаленій, гіпервіддаленій чи навіть історичній перспективах. Для посилення точності виміру економічної ефективності необхідно перейти від виміру статичної до виміру квазідинамічної, динамічної, гіпердинамічної та історичної ефективності.
\end{abstract}

Ключові слова: ефективність економічних систем; економічний ефект; інтегральний економічний ефект.

Вступ. Сучасний етап розвитку як перехідних, так i розвинених економічних систем характеризується високим динамізмом соціально-економічного розвитку, кардинальними змінами у визначенні векторів суспільного прогресу. Головною рушійною силою пришвидшеного розвитку тих чи інших економічних систем є інтереси людини і пришвидшене зростання іiі потреб. Відповідно, зростання багатства суспільства є головним критерієм ефективності функціонування і подальшого розвитку економічних систем. Проблема ефективності функціонування економічних систем є актуальною не тільки в теоретичному, а й в практичному відношенні.

Аналіз останніх досліджень та публікацій. Проблему функціонування економічних систем, визначення місця та ролі економічних та соціальних критеріїв економічного розвитку відображено в працях відомих українських вчених - Г. І. Башнянина $(2010,2013)$, Л. Я. Гончарук (2000, 2001), О. I. Дунаса, О. І. Ковтун (2000), О. В. Хом'яка, Б. М. Шевчика і Ю. І. Турянського (2000) та ін.

Проте залишається багато невирішених актуальних питань, пов'язаних із дослідженням економічної ефективності функціонування економічних систем, із дослідженням впливу економічних і соціальних процесів на результати економічної діяльності, тобто на зміну рівня економічної ефективності. Зокрема, подальшого дослідження потребує проблема виміру ефективності функціонування економічних систем.

Мета роботи - дослідити методологічну проблему виміру рівня ефективності функціонування економічних систем у контексті повнішого виміру результативності їх діяльності.

Викладення основного матеріалу. Ефективність функціонування економічних систем визначається як співвідношення інтегральних (загальних) чи диференціальних (приростних) величин економічного ефекту й економічних витрат. Для точного виміру рівня економічної ефективності варто у повному обсязі вирахувати як економічний ефект, так і економічні витрати. На підставі співвідношення цих двох параметрів отримаємо точне значення рівня економічної ефективності. У повному обсязі визначення с економічних витрат (знаменника формули економічної ефективності) не має особливих труднощів, оскільки ці витрати в повному обсязі реалізуються в кожен поточний момент часу. Однак економічний ефект поточних економічних витрат проявляється не тільки у поточний момент часу, а й у віддаленому і гіпервіддаленому періодах часу (або навіть в

Інформація про авторів:

Башнянин Григорій Іванович, д-р екон. наук, професор, завідувач кафедри теоретичної та прикладної економіки. Email: iraan@ukr.net

Свінцов Олександр Миколайович, д-р екон. наук, професор, кафедра економіки та менеджменту. Email: iraan@ukr.net Коцупей Володимир Михайлович, канд. екон. наук, доцент, кафедра менеджменту. Email: iraan@ukr.net

Цитування за ДСту: Башнянин Г. І., Свінцов О. М., Коцупей В. М. Економічна ефективність функціонування господарських систем: проблема вимірювання. Науковий вісник НЛтУ України. Серія Економічна. 2018, т. 28, № 4. С. 9-14

Citation APA: Bashnyanin, G. I., Svincov, O. M., \& Kocupej, I. M. (2018). Economic Efficiency of Functioning of Economic Systems: Measurement Problem. Scientific Bulletin of UNFU, 28(4), 9-14. https://doi.org/10.15421/40280401 
історичному періоді часу, який виходить за межі гіпердовготривалого ринкового періоду). 3 огляду на це для переходу до точного виміру рівня економічної ефективності варто зіставляти послідовно поточні економічні витрати $з$ економічним ефектом не тільки поточних, а й віддалених періодів часу (Bashnyanin et al., 2012b; Bashnyanin, Tretyak \& Buryk, 2010).

Економічна теорія і сучасний економічний аналіз оперують дуже еластичними поняттями короткотривалого, довготривалого і гіпердовготривалого ринкових періодів. Зміст цих понять цілком і повністю детермінується змістом тих економічних і неекономічних процесів, які в них і через них (фактор часу не можна розглядати тільки як одну із формальних координат економічного функціонування і економічного розвитку, якби воно було так і тільки так, тоді б часова координата економічного функціонування і економічного розвитку була нічим іншим, як тільки формальним інструментом економічного аналізу) проявляються. У сучасній економічній теорії керуються вищим, а не елементарним уявленням про співвідношення економічного часу й економічної матерії. Сучасна філософська думка виділяє два типи зв'язку між економічним часом і економічною матерією (Bashnyanin, Kopich \& Chupik, 2001; Bashnyanin, Goncharuk \& Mikhaylyak, 2012).

Перший - це елементарний чи нижчий зв'язок, коли економічний час розглядають тільки як формальну координату економічного розвитку й економічного функціонування. На підставі такого елементарного або нижчого уявлення про їх зв'язок можна сформувати тільки формальну економічну концепцію. Вона формальна не в тому розумінні, що передбачає використання формальних і формально-математичних прийомів, а в тому, що концепція беззмістовна, така, що не стосується основного змісту і суті тих чи інших економічних процесів. Формальним за своїм характером $є$ економічний аналіз, який абсолютно ігнорує фактор часу (тобто розглядає його тільки як формальну і зовнішню координату економічного розвитку).

У цьому контексті досить формальний і елементарний характер має марксистська політична економія, у ній абсолютно не прийнято було досліджувати економічні процеси через призму короткотривалого періоду. Точніше, вона розглядала фактор часу як не віддиференційований і досліджувала економічні процеси безвідносно до того, в якому періоді часу реалізуються ті чи інші економічні процеси. Ще точніше, вона зазвичай у певному ринковому періоді досліджує ті чи інші економічні процеси - або в короткотривалому, або в довготривалому, або в гіпердовготривалому періодах часу. Проте результати економічного аналізу вона абсолютизує, приписує їх або іншому ринковому періоду, що, звичайно, є рідкісним явищем, або взагалі розглядає як такі, що властиві для будь-якого періоду (Bashnyanyn, 2010, 2010).

Такий невіддиференційований підхід у розумінні фактора економічного часу дуже небезпечний для результатів дослідження: він $є$ прямим шляхом до абсолютизації і гіпертрофації економічної картини світу й економічних концепцій. Зазвичай, невіддиференційований підхід у розумінні фактора часу в економічному аналізі властивий для недосвідчених дослідників, вчених-початківців, які схильні через недостатній рівень кваліфікації (або власний практичний досвід) до гіпер- трофації чи навіть абсолютизації (крайній варіант) тих економічних поглядів, які вони сформулювали й отримали в лоні абстрактно-часового економічного аналізу (Bashnyanin, 2010; Goncharuk, 2001).

Другий тип зв'язку між економічним часом і економічною матерією (під економічною матерією розуміємо певні економічні процеси, певну практику господарювання) - це вищий (високий) зв'язок, згідно з яким економічний час розглядають як невід'ємний атрибут економічної матерії, як іiї внутрішній момент (Goncharuk, 2000, 2001).

Розуміння економічного часу в різних системах економічної теорії різне і зумовлене тими реальними процесами, в яких і через які проводять аналіз цієї економічної категорії. Економічний час розуміють по-різному у "виробничій", "ринковій" і "споживчій" системах економічної теорії і відповідних цим системам школах політичної економії. У марксистській, а також у класичній і сучасній новій класичній школах політичної економії економічний час розуміють у суто виробничому аспекті як той чи інший період часу, який відділяє певну економічну дію (наприклад економічні витрати ресурсів) від певних економічних результатів (наприклад випуску того чи іншого обсягу продукції або надання того чи іншого обсягу економічних послуг). Цей період часу і називають виробничим лагом. Залежно від його тривалості, виділяють різні типи економічного аналізу. По-перше, це статичний економічний аналіз, коли допускається, що величина часу між економічними витратами, наприклад, і економічними результатами дорівнює або майже дорівнює нулю. По-друге, це динамічний економічний аналіз, який уже базується на тому, що існує певний лаг між економічними витратами й економічними результатами. Динамічний економічний аналіз також може бути різний, залежно від тривалості (чи, точніше, величини) зазначеного вище лагу: квазідинамічний (коли лаг незначний), динамічний (коли лаг значний), гіпер- чи метадинамічний (коли лаг гіперзначний) і навіть історичний (крайній випадок виробничого динамічного аналізу, за якого економічні результати від певної економічної дії отримуємо тільки у віддаленій історичній перспективі або, у кращому разі, в найближчій, але все-таки історичній, перспективі).

Отже, виділяють і різні типи економічної ефективності функціонування певних економічних систем: статичну, квазідинамічну, динамічну, гіпердинамічну та історичну. Вимірюючи статичну ефективність (маємо на увазі тільки економічні аспекти ефективності, а не соціальні та соціально-духовні) розглядаємо і економічні витрати, і економічні результати в дещо "зрізаному" вигляді. Вимірюючи квазідинамічну, динамічну чи гіпердинамічну ефективності, бачимо економічні результати в їх повноті й завершеності. Зрозуміло, що повнота виміру певних економічних результатів зростає з розширенням лагу, тому рівні квазідинамічної, динамічної і гіпердинамічної ефективності будуть різними. Якщо умовно прийняти, що статична ефективність (у статичній економіці, в якій віддалені економічні ефекти відсутні, а наявні тільки поточні економічні ефекти, наприклад, абсолютно всі економічні витрати матеріалізуються в економічні результати на поточний момент часу, що практично нереально, але в суто теоретичному аналізі, який не претендує на високу точність, допустимо) дорівнює одиниці (тобто утримується на нормаль- 

ся $з$ економічними доходами, причому економічні витрати розглядають як повні витрати, тобто включають нормальний прибуток як функцію таких специфічних витрат, як підприємницькі здібності), то квазідинамічна, динамічна і гіпердинамічна ефективності будуть більшими від одиниці 3 тією тільки відмінністю, що остання віддалятиметься від одиниці, а попередні знахо-

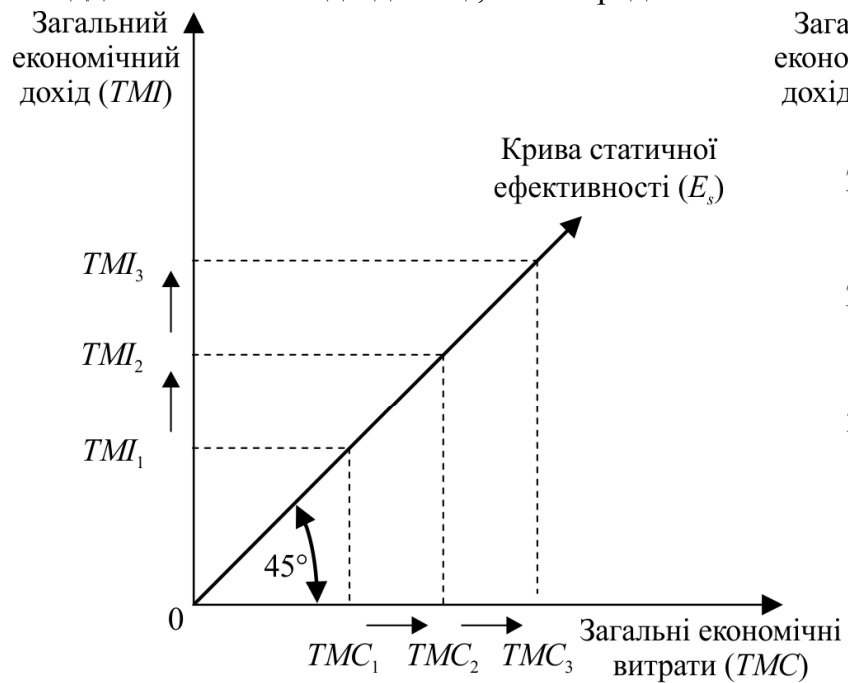

Рис. 1. Крива статичної ефективності в статичній економіці (економічній системі) (варіант гіперкороткотривалого ринкового періоду) ному рівні, за якого економічні витрати врівноважують-

дитимуться на ближчій відстані від неї. Графічно цю ситуацію можна зобразити кривими (або прямими, якщо період аналізу короткотривалий чи гіперкороткотривалий), які на різну відстань відхиляються від бісектриси, побудованої за принципом зрівноваження економічних витрат і економічних доходів у статичній економіці (рис. 1), а з розширенням довжини лагу віддаляються від неї (рис. 2, 3).

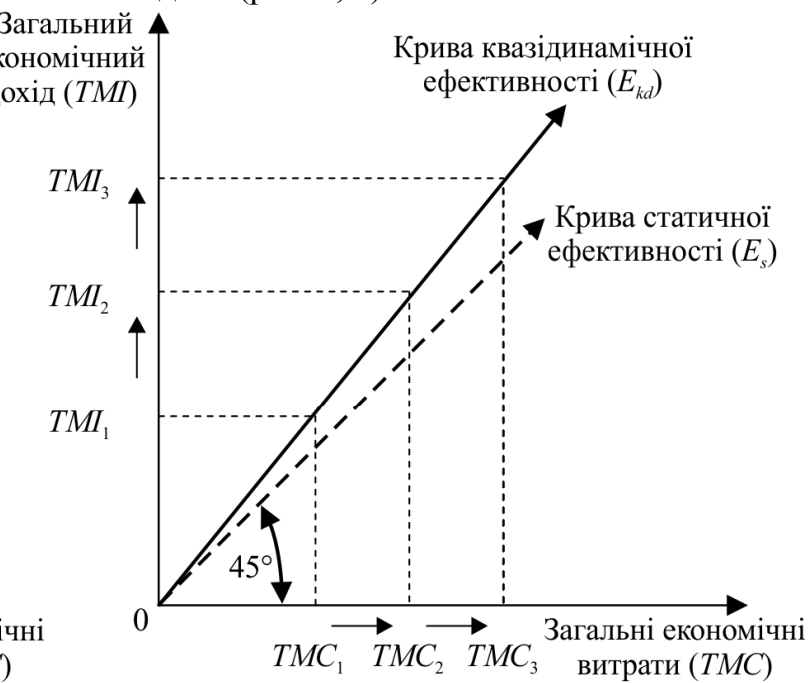

Рис. 2. Крива квазідинамічної ефективності в квазідинамічній економіці (варіант гіперкороткотривалого ринкового періоду) Джерело: складено на основі (Bashnyanin, Turyanskiy \& Dunas, 2013; Bashnyanin, Kopich \& Chupik, 2001)
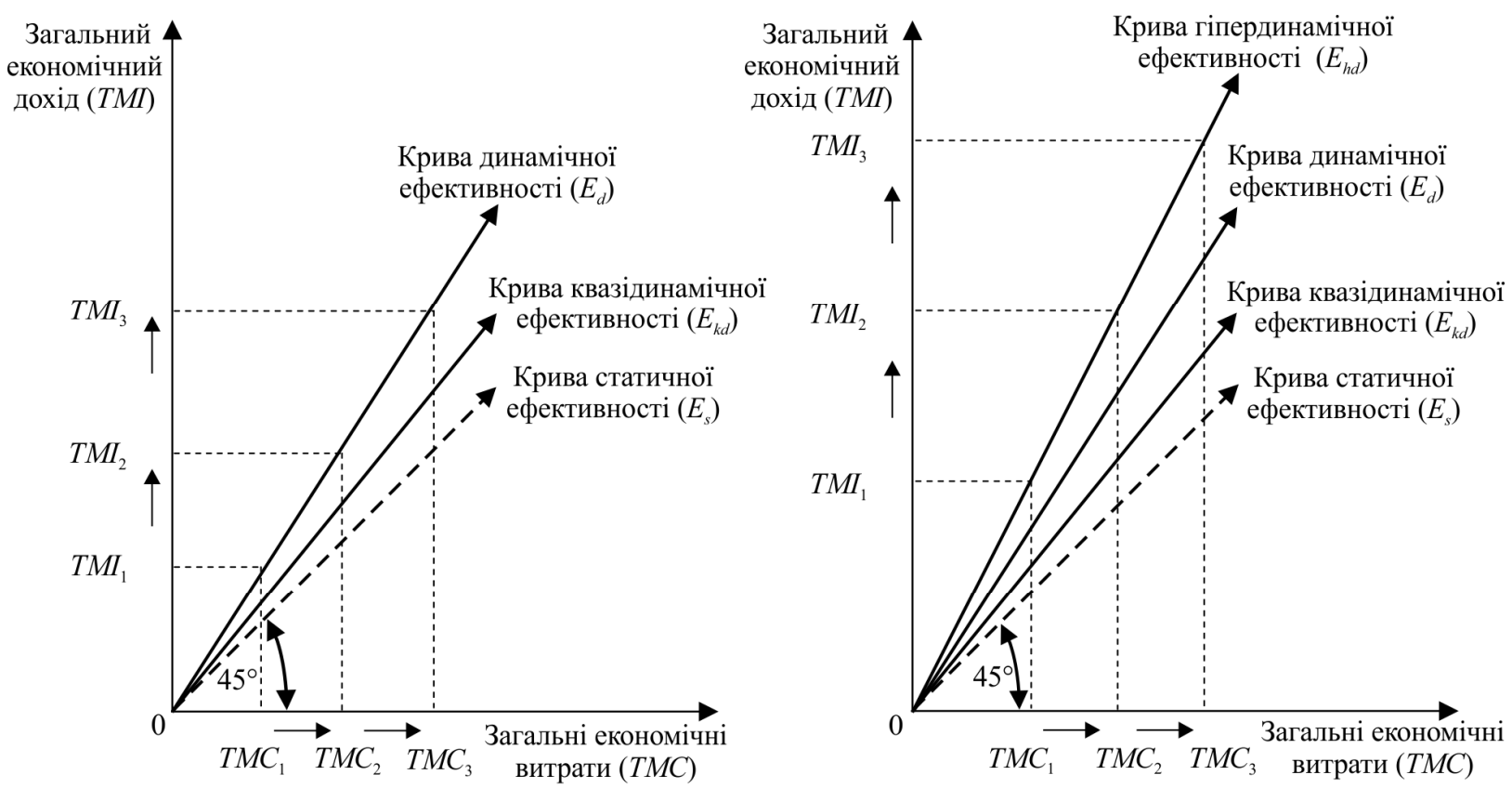

Рис. 3. Крива динамічної ефективності в динамічній економіці

(варіант гіперкороткотривалого ринкового періоду)

Джерело: складено на основі (Bashnyanin et al., 2012a, 2012b).

Гіпердинамічна економічна ефективність ще більше відхиляється від статичної економічної ефективності (рис. 4). Це тому, що навіть у гіпердинамічному інтервалі часу не всі економічні ефекти від певних економічних витрат проявляються в повному обсязі. $Є$ підстави вважати, що економічні витрати вичерпуються повністю (тобто матеріалізуються в економічні результати, що, в принципі, можливо) тільки за межами навіть гіпердинамічного періоду часу, тобто тільки в історичному контексті. Це дає нам підстави виділити ще такий тип економічної ефективності, як історична ефективність (чи метагіпердинамічна - цей варіант іiї назви вдаліший і зрозуміліший).

Варто зазначити, що найвіддаленіші від поточного моменту часу (тобто вже в історичній перспективі, найближчій чи віддаленій) результати певних економічних витрат - це соціальні й особливо соціально-духовні ефекти. Тому криві (прямі, якщо брати до уваги найапроксимованіший їх варіант, тобто в гіперкороткотривалому ринковому періоді проводити економічний аналіз) 
соціальної і особливо соціально-духовної ефективності гіпердинамічного типу ще більше відхиляються вгору від кривої нормальної (одиничної) ефективності (рис. 5).

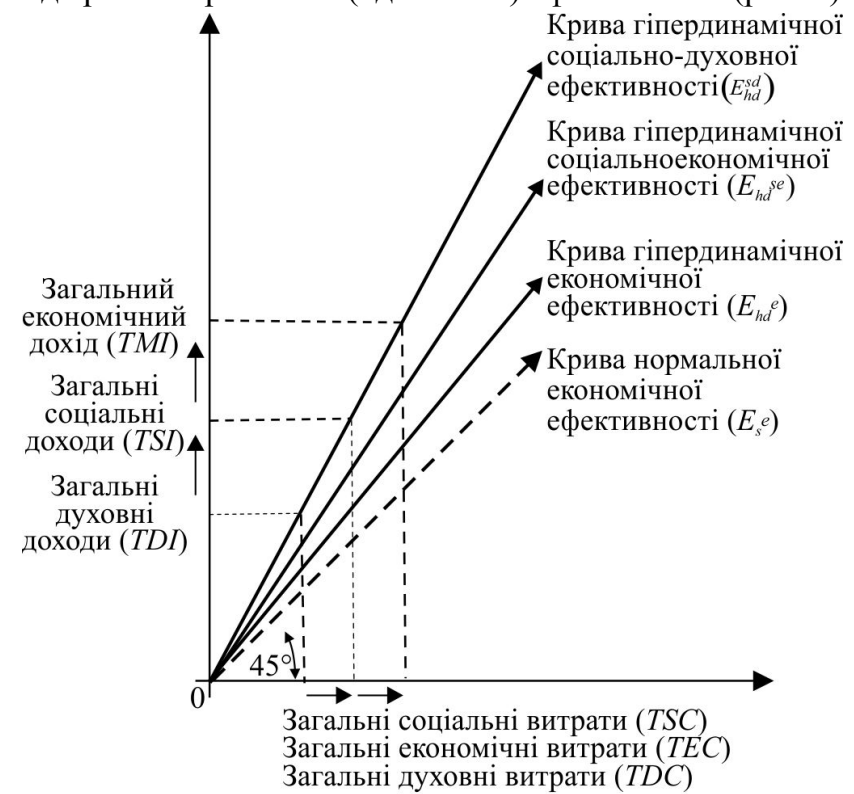

Рис. 5. Крива гіпердинамічної: а) економічної; б) соціальноекономічної; в) соціально-духовної ефективності (варіант гіперкороткотривалого ринкового періоду). Складено на основі

(Bashnyanin, Turyanskiy \& Dunas, 2013; Bashnyanin et al., 2012a)

Отже, зазначене вище означає, що соціальні й особливо соціально-духовні наслідки (ефекти) певних економічних витрат важче вловимі, навіть 3 позицій гіпердинамічного виробничого економічного періоду. Вони дуже часто проявляються за межами життя певного покоління, а тому їх не помічають і не беруть до уваги. Це також означає, що крива гіпердинамічної соціальної і соціально-духовної ефективності відхиляється вгору від кривої статичної ефективності, вона завжди або майже завжди перебуває на певній відстані від останньої. Тому тільки історичний контекст аналізу рівнів соціальної і соціально-духовної ефективності дає принципову можливість максимально точно їх визначити. Поза цим історичним аспектом і історичним аналізом не можемо виявити точно рівень соціальної і соціальнодуховної ефективності функціонування певних економічних систем тому, що значна частина (або досить відчутна) наслідків певних соціальних і соціально-духовних витрат проявляється і реалізується тільки в межах відносно віддаленого історичного періоду. Якщо в межі цього періоду не вводимо науковий аналіз, то цим самим беремо до уваги більш чи менш значну, але все-таки тільки частину наслідків певних процесів у певній економічній системі (Kovtun, Trichoma \& Goncharuk, 2000; Shevchik, Goncharuk \& Turyanskiy, 2000).

Це дає нам підстави також вважати, що перехід від квазідинамічного до динамічного, гіпердинамічного, метагіпердинамічного (тобто вже фактично історичного) аналізу проблеми як економічної, так і соціальноекономічної й соціально-духовної ефективності - це одночасно перехід від неточного до точного, від менш точного до більш точного економічного (соціально-економічного, соціально-духовного) виміру. Квазідинамічний аналіз і вимір економічної ефективності квазіточний, а динамічний і гіпердинамічний (а також метагіпердинамічний) - умовно-точний і точний. У контексті зазначеного вище може виникнути думка, що статич- ний аналіз найточніший, оскільки він передбачає врахування як усіх економічних витрат, так і всіх економічних результатів. Проте тільки в теоретичному статичному аналізі виходимо 3 передумови, що лаг часу між витратами і результатами дорівнює нулю, а в результатах відображено всі економічні ефекти здійснених витрат. Насправді ж у реальній практиці і в реальному економічному аналізі статичного типу вловлюємо тільки незначну частину економічних результатів певного економічного процесу. Тому завжди треба мати на увазі, що статична ефективність буває двох типів. По-перше, номінальною, вона завжди дорівнює одиниці, тобто $є$ за своїм характером нормальною ефективністю (рис. 6).

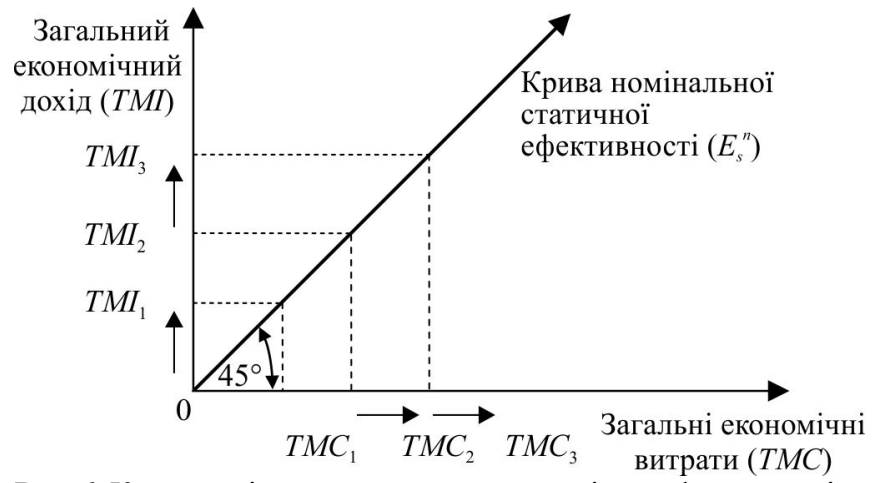

Рис. 6. Крива номінальної статичної економічної ефективності (варіант гіперкороткотривалого ринкового періоду). Складено на основі (Bashnyanin, Tretyak \& Homyk, 2010; Bashnyanin, Kopich \& Chupik, 2001)

По-друге, реальна статична ефективність. Під час визначення реальної статичної ефективності ми повинні брати до уваги тільки ті економічні результати, які проявляються у поточний момент часу; вони зазвичай бувають незначні або навіть близькі до нуля (тільки за певний період економічні витрати зможуть "принести" якісь результати). Зв'язок між номінальною і реальною статичною економічною ефективністю (i, відповідно, соціально-економічною, соціально-духовною) наочніше проявляється, коли їх зображати в термінах моделі "ефективність - обсяги виробництва чи грошовий дохід від економічної діяльності". Крива номінальної статичної економічної ефективності займає в цьому випадку горизонтальне положення на рівні "1", а крива реальної статичної ефективності лежить під нею і незначно здіймається вгору, зі збільшенням масштабів діяльності (а отже, і з розширенням часового лагу функціонування певної економічної системи) (рис. 7,8 ).

Аналогічно можна виділити також номінальну i peальну квазідинамічну, динамічну i гіпердинамічну ефективність (як, власне, економічного, так і соціальноекономічного та соціально-духовного порядку).

Висновки. Економічну ефективність функціонування економічних систем визначають як співвідношення економічного ефекту й економічних витрат. Економічні витрати формуються в кожен конкретний момент часу. Внаслідок зіставляння поточного економічного ефекту (в короткотривалому періоді) з поточними економічними витратами отримаємо неточне або номінальне значення економічної ефективності, оскільки економічний ефект проявляється через певний лаг часу, який може бути доволі значним. Реальне значення рівня ефективності отримаємо тоді, коли будемо зіставляти поточні економічні витрати зі сумарним ефектом, який формується у віддаленій, гіпервіддаленій чи навіть історичній перспективі. 


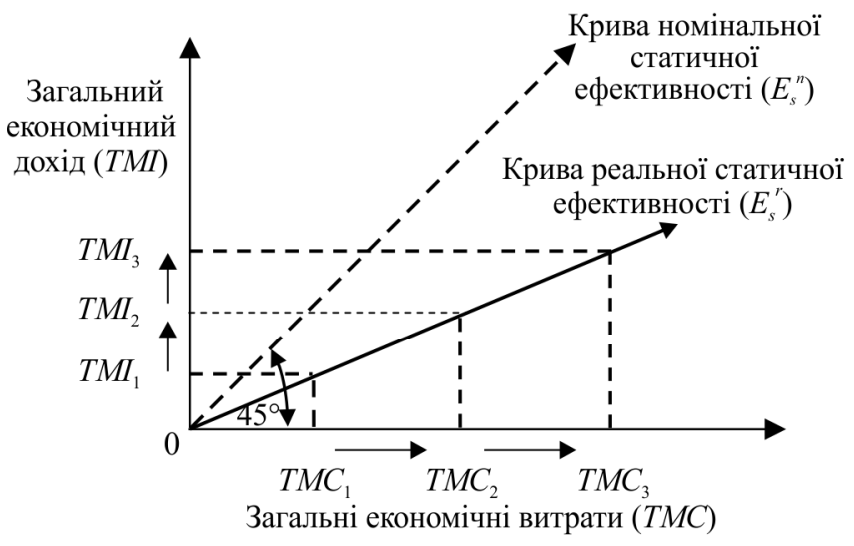

Рис. 7. Крива реальної статичної економічної ефективності (варіант гіперкороткотривалого ринкового періоду)

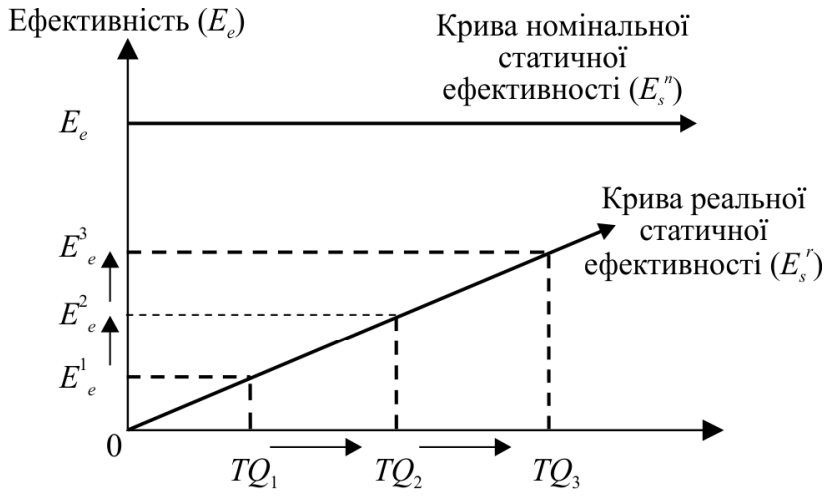

Загальний економічний дохід (TMI)

Загальні обсяги виробництва $(T Q)$

Рис. 8. Криві номінальної і реальної статичної ефективності в термінах моделі

"ефективність - масштаби виробництва"

Джерело: складено на основі (Bashnyanin, Turyanskiy \& Dunas, 2013; Bashnyanin, Kopich \& Chupik, 2001)

3 метою посилення точності виміру економічної ефективності необхідно перейти від виміру статичної до виміру квазідинамічної, динамічної, гіпердинамічної та історичної ефективності. Найточнішим буде такий вимір рівня ефективності, який враховує сумарний економічний ефект від неї, що формується в короткотривалому, довготривалому, гіпердовготривалому й історичному періодах часу. Для максимально точного виміру економічної ефективності потрібно враховувати не тільки економічну, а й соціально-економічну і соціально-духовну складову інтегрального ефекту, оскільки економічні витрати сьогодні не тільки підвищують продуктивність праці й капіталу, а й визначають соціальноматеріальний і соціально-духовний розвиток людини.

\section{Перелік використаних джерел}

Bashnyanin, G. I., \& Goncharuk, L. Y. (2010). Efficiency of socialization of the economic systems: methodological problems of metrology analysis. New World-2000. 240 p.

Bashnyanin, G. I., Goncharuk, L. Y., \& Mikhaylyak, I. V. (2012). Socializacion efficiency of the economic systems at the terms of strengthening of globalizacion processes. Scientific Bulletin of UNFU, 22(14), 189-197. [In Ukrainian].

Bashnyanin, G. I., Kopich, I. M., \& Chupik, I. O. (2001). Mikro ekonomich market systems: metrology problems of analysis of efficiency of functioning. LKA.182 p.

Bashnyanin, G. I., Selskiy, A. A., Turyanskiy, Y. I., \& Kundickiy, O. O. (2012a). Efficiency of Liberalization of the economic systems. Scientific Bulletin of UNFU, 22(14), 166-173. [In Ukrainian].

Bashnyanin, G. I., Selskiy, A. A., Turyanskiy, Y. I., \& Kundickiy, O. O. (2012b). The Basic metrology types of liberalization efficiency of the economic systems. Efficiency of state administration, 33, 245-253.

Bashnyanin, G. I., Tretyak, G. S., \& Buryk, N. B. (2010). Regulator efficiency of the economic systems. Scientific Bulletin of UNFU, 20(9), 134-141. [In Ukrainian].

Bashnyanin, G. I., Tretyak, M. S., \& Homyk, M. S. (2010). Deregulyaciyna elasticity of the economic systems: concept, general formula, types and kinds. Scientific Bulletin of UNFU, 20(11), 81-90. [In Ukrainian].

Bashnyanin, G. I., Turyanskiy, Y. I., \& Dunas, O. I. (2013). Sentinel efficiency of liberalization of the economic systems. Scientific Bulletin of UNFU, 23(10), 132-139. [In Ukrainian].

Bashnyanin, G. I., Turyanskiy, Y. I., \& Dunas, O. I. (2013). To the question of negative efficiency of market self-regulation of the economic systems. Scientific Bulletin of UNFU, 23(7), 120-124. [In Ukrainian].

Bashnyanyn, G. I. (2012). Methological of economic systems: introduction info the general theory and methodology of formation of economic parameters. Publishing house of Lviv Commercial Academy. $1152 \mathrm{p}$.

Goncharuk, L. Y. (2000). About socializacion efficiency of the economic systems: a concept and general formula of, NAN of Ukraine. 395-404.

Goncharuk, L. Y. (2001). Efficiency social policy in the conditions of market transformations: problems of socialization of economic development. NAN of Ukraine. $16 \mathrm{p}$.

Kovtun, O. I., Trichoma, O. I., \& Goncharuk, L. Y. (2000). Strategic directions of new economic policy in a context organizationally economic reforms KDTEU. 114-116.

Shevchik, B. M., Goncharuk, L. Y., \& Turyanskiy, Y. I. (2000). Tipologizacion transitional economic systems NAN of Ukraine. 129134

Г. И. Башнянин 1 , О. М. Свинцов ${ }^{2}$, В. М. Коцупей ${ }^{1}$

${ }^{1}$ Львовский торгово-экономический университет, г. Львов, Украина ${ }^{2}$ Дрогобычский государственный педагогический университет им. Ивана Франко, г. Дрогобыч, Украина

\section{ЭКОНОМИЧЕСКАЯ ЭФФЕКТИВНОСТЬ ФУНКЦИОНИРОВАНИЯ ХОЗЯЙСТВЕННЫХ СИСТЕМ: ПРОБЛЕМА ИЗМЕРЕНИЯ}

Проведен научный анализ проблемы эффективности экономических систем в контексте измерения ее точности. Исследован суммарный экономический эффект в кратковременном, длительном, гипердлительном и историческом временных периодах. Предложено перейти от измерения статической к измерению квазидинамической, динамической, гипердинамической, а также исторической экономической эффективности функционирования экономических систем. С целью более точного измерения эффективности обосновано использование интегрального экономического эффекта, включающего экономическую, социально-экономическую и социально-духовную составляющие. Сделан вывод о том, что экономическая эффективность функционирования экономических систем определяется как соотношение экономического эффекта и экономических расходов. Экономические расходы формируются в каждый конкретный момент времени. В результате сопоставления текущего экономического эффекта (в кратковременном периоде) с текущими экономическими расходами можно получить неточное или номинальное значение экономической эффективности, поскольку экономический эффект проявляется через 
определенный лаг времени, который может быть достаточно значим. Реальное значение уровня эффективности получим тогда, когда будем сопоставлять текущие экономические расходы с суммарным эффектом, который формируется в отдаленной, гиперотдаленной или даже исторической перспективах. С целью усиления точности измерения экономической эффективности, необходимо перейти от измерения статической к измерению квазидинамической, динамической, гипердинамической и исторической эффективности.

Ключевые слова: эффективность экономических систем; экономический эффект; интегральный экономический эффект.

G. I. Bashnyanin', O. M. Svincov', I. M. Kocupej1

${ }^{1}$ Lviv University of Trade and Economics, Lviv, Ukraine

${ }^{2}$ Drohobych State Pedagogical University named after Ivan Franko, Drohobych, Ukraine

\section{ECONOMIC EFFICIENCY OF FUNCTIONING OF ECONOMIC SYSTEMS: MEASUREMENT PROBLEM}

The modern stage of development of both transitional and developed economic systems is characterized by high dynamism of socio-economic development, and cardinal changes in determination of public progress vectors. The main driving force behind the accelerated development of certain economic systems is man's interests and the accelerated growth of his needs. Accordingly, the growth of the wealth of society is a key criterion for the effective functioning and further development of economic systems. The problem of the effectiveness of the functioning of economic systems is relevant not only in the theoretical but also in practical terms. Therefore, the purpose of the research is methodological problem of measuring of the level of economic efficiency of functioning of economic systems. However, there remain many important issues concerning the study of the economic efficiency of the functioning of economic systems, the study of the impact of economic and social processes on the results of economic activity, that is, to change the level of economic efficiency. In the course of research the scientific analyses of problems of the efficiency of economic systems in the context of its measurement accuracy is made. The total economic impact in the short-term, long-term, hiperlong-term and historical time period is considered. The transition from measurement of static efficiency socialization to measurement kvazidynamic, dynamic, hyperdynamic and historical types of economic efficiency of economic systems functioning, using economic integral effect are substantiated. The authors have come to the conclusion that economic efficiency of functioning of the economic systems is determined as correlation of economic effect and economic charges. Economic charges are formed in every particular moment of time. As a result of comparison of current economic effect (in a short period) with current economic outlays will get the inexact or nominal value of economic efficiency, as an economic effect shows up through certain lag of time, which can be sufficiently considerable. We can get the real value of the level of efficiency, when we compare current economic outlays with a total effect which is formed in a remote, hyperremote or even historical prospect.

Keywords: efficiency of economic systems; economic effect; integral economic effect. 